University for Business and Technology in Kosovo

UBT Knowledge Center

UBT International Conference

2017 UBT International Conference

Oct 27th, 1:00 PM - 2:30 PM

\title{
Diversification of Polish agri-food trade
}

\author{
Malgorzata Bulkwoska \\ Institute of Agricultural and Food Economics - National Research Institute (IAFE-NRI), Poland, \\ Malgorzata.Bulkowska@ierigz.waw.pl
}

Follow this and additional works at: https://knowledgecenter.ubt-uni.net/conference

Part of the Business Commons

\section{Recommended Citation}

Bulkwoska, Malgorzata, "Diversification of Polish agri-food trade" (2017). UBT International Conference.

245.

https://knowledgecenter.ubt-uni.net/conference/2017/all-events/245

This Event is brought to you for free and open access by the Publication and Journals at UBT Knowledge Center. It has been accepted for inclusion in UBT International Conference by an authorized administrator of UBT Knowledge Center. For more information, please contact knowledge.center@ubt-uni.net. 


\title{
Diversification of Polish agri-food trade
}

\author{
Małgorzata Bułkowska \\ Institute of Agriculture and Food Economics - National Research Institute, Poland \\ bulkowska@ierigz.waw.pl
}

\begin{abstract}
The embargo introduced in August 2014 by Russia on the food products imported from the European Union caused a strong decline in sales of food from Poland in this country. The aim of the article is to analyse the current trends and prospects of development of Polish agrifood trade with the EU and non-EU countries in 2013-2016. A special attention was paid on changes in geographical structure and the level of diversification of Polish food exports as a result of the export restriction. The analysis shows that the situation on the Russian market influenced the growth of the food exports from Poland both to the EU and non-UE markets. In the recent years, the role of third countries in Polish exports of agri-food products has steadily increased, however the trade with these countries is still relatively low and concentrated on selected products.
\end{abstract}

Keywords: food industry, foreign trade, diversification, Herfindahl-Hirschman Index

\section{Introduction}

Despite many adverse external circumstances which have affected the Polish agri-food sector in recent years, the export of Polish food still shows an upward trend, but its growth rate is becoming weaker. In 2016, the Polish import grew faster than the export. As a result, the surplus of the export over the import has decreased for the first time for many years. The weakened growth rate of the export was determined by, inter alia, administrative restrictions, such as the Russian embargo and restrictions introduced in connection with the detection of African swine fever (ASF) in wild boar [1]. For many years, the major customer and the market for Polish food have been the European Union countries, however, the potential import of these countries is limited. After introducing the restrictions by Russia, which belonged to the largest non-EU import markets of Polish food, it became necessary to reorient the export to other markets, including, Asian and African. The growth of EU trade (including Poland) with third countries is expected to benefit from free trade agreements concluded by the Union with the individual countries [4] as well as numerous government programmes supporting the development of the Polish export to non-EU markets [5].

\section{Materials and Methods}

The article analysed the changes in the volume, structure and directions of the Polish agri-food export in the years 2010-2016, with special attention paid to the trends which have taken place in recent years and it also assessed the degree of diversification of the Polish agri-food export. The analysis of trade flows has been carried out based on the data from the WITS-Comtrade database. Agri-food products include the HS sections 01-24. In order to assess the export concentration level, the Herfindahl-Hirschman Index (HHI) has been used [6]. The HHI 
concentration index takes values from 0 to 1 . The lower is the index, the lower is the concentration of the objective structure of the export. The HHI index has been calculated according to the formula:

where:

$$
H H I=\frac{\sum_{i=1}^{n} s_{i}^{2}-\frac{1}{n}}{1-\frac{1}{n}}
$$

HHI - Herfindahl-Hirschman Index

si - share of the value of the ith commodity group in the export of a given country (here: six-digit HS classification)

$\mathrm{n}$ - number of commodity groups in the export of a given country

\section{Results and Discussion}

\section{Geographical structure of the Polish agri-food export}

Poland's accession to the European Union was followed by the dynamic development of the Polish agri-food export. In recent years, the export growth rate has started slowing down, mainly due to the difficulties associated with the embargo introduced in 2014 by Russia [3]. In 2016 the value of the Polish export amounting to USD 25.5 billion, but, compared to 2013, it decreased by 5\% (Fig. 1). The largest importers of food from Poland are EU countries, which share about $80 \%$. In 2016, the sale to the European Union countries slightly decreased $(2,3 \%)$, reaching the value of USD 20.5 billion. This means that further possibilities of increasing the export to the EU market are limited, therefore there is a need to find new markets for surpluses of domestic production [5].

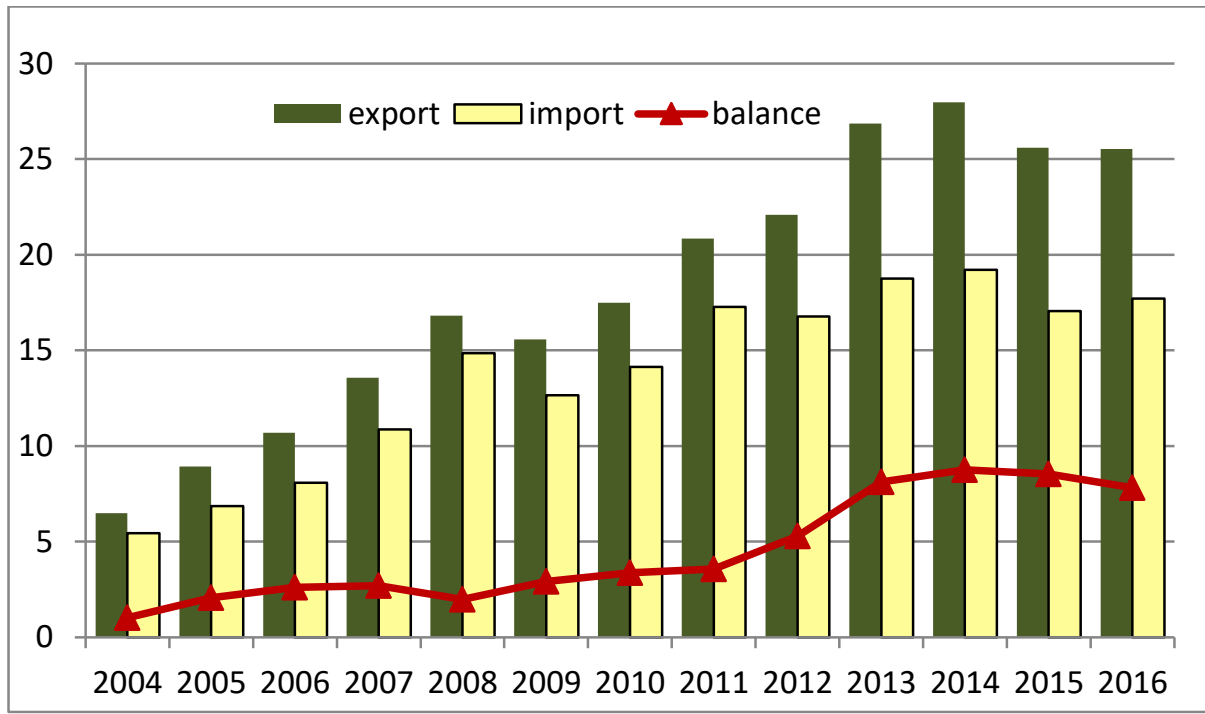

Fig. 1. Poland's agri-food trade in 2004-2016 [billion USD] 
In 2016, as usual, the largest quantity (1/5) of agri-food products was sold to Germany (22.2\%), another largest customer of Polish food was Great Britan with the share of $8.8 \%$, then the Czech Republic (6.5\%), Italy (5.6\%), the Netherlands (5.5\%) and France (5.1\%) [3]. In 2016, compared to 2013 , the export of agri-food commodities to the non-EU countries decreased by $15 \%$ to USD 5.0 billion. It resulted mainly from significant (about 75\%) decrease of Polish agri-food export to Russia, but also to Ukraine (41\%) and to Belarus $(5,0 \%)$. As a result of the embargo introduced in 2014, Russia moved down from the third (after Germany and Great Britan) to fifteenth position among the largest importers of Polish food. Despite this, it is still the largest recipient of Polish food among non-EU countries, but its share decreased from $6.2 \%$ to $1.6 \%$ (table 1). The second largest customers of agri-food products from Poland among non-EU countries were the United States (increase in the export value by $25 \%$ when compared to 2013), Saudi Arabia (increase by 90\%) and Hong Kong (nearly double increase in the export).

Table 1. Geographical structure of Polish agri-food export in 2013 and 2016

\begin{tabular}{|r|r|r|r|r|r|c|}
\hline \multirow{2}{*}{ Destination } & \multicolumn{3}{|c|}{ Value of export } & \multicolumn{3}{c|}{ Share of export } \\
& \multicolumn{3}{|c|}{ in mln USD } & \multicolumn{3}{c|}{ in } \\
\cline { 2 - 7 } World & 2010 & 2013 & 2016 & 2010 & 2013 & 2016 \\
\hline UE-28 & $\mathbf{1 7 4 9 9}$ & $\mathbf{2 6 ~ 8 6 9}$ & $\mathbf{2 5 ~ 5 3 2}$ & $\mathbf{1 0 0}$ & $\mathbf{1 0 0}$ & $\mathbf{1 0 0}$ \\
\hline Germany & $\mathbf{1 3 \mathbf { 8 3 3 }}$ & $\mathbf{2 1 ~ 0 1 8}$ & $\mathbf{2 0 ~ 5 3 3}$ & $\mathbf{7 9 , 4}$ & $\mathbf{7 8 , 2}$ & $\mathbf{8 0 , 4}$ \\
\hline United Kingdom & 1223 & 6204 & 5680 & 22,7 & 23,1 & 22,2 \\
\hline Czech Republic & 1087 & 1619 & 1667 & 6,2 & 6,0 & 6,5 \\
\hline Italy & 998 & 1404 & 1425 & 5,7 & 5,2 & 5,6 \\
\hline Netherlands & 992 & 1389 & 1405 & 5,7 & 5,2 & 5,5 \\
\hline France & 1062 & 1572 & 1314 & 6,1 & 5,9 & 5,1 \\
\hline Extra UE & $\mathbf{3 6 0 5}$ & $\mathbf{5 8 5 1}$ & $\mathbf{4 9 9 9}$ & $\mathbf{2 0 , 6}$ & $\mathbf{2 1 , 8}$ & $\mathbf{1 9 , 6}$ \\
\hline Russia & 993 & 1669 & 417 & 5,7 & 6,2 & 1,6 \\
\hline United States & 310 & 332 & 416 & 1,8 & 1,2 & 1,6 \\
\hline Saudi Arabia & 56 & 204 & 388 & 0,3 & 0,8 & 1,5 \\
\hline Belarus & 209 & 389 & 370 & 1,2 & 1,4 & 1,4 \\
\hline Ukraine & 467 & 607 & 361 & 2,7 & 2,3 & 1,4 \\
\hline Hong Kong & 61 & 91 & 208 & 0,4 & 0,3 & 0,8 \\
\hline
\end{tabular}

\section{Commodity structure of the Polish agri-food export}

The commodity structure of the Polish agri-food export differed depending on the country of destination. In 2016, the export both to EU countries (including the largest customers of Polish food, i.e. Germany, Great Britain, the Czech Republic, the Netherlands and Italy), as well as to other significant non-EU importers (the United States, Saudi Arabia or Belarus) increased. On the other hand, the share of Russia and Ukraine decreased.

In 2016, Poland exported mainly poultry meat, cigarettes, chocolate products, cereal products (biscuits, waffles, etc.), beef, sugar syrups, pork, wheat, smoked fish (especially salmon), cheese and curd, processed and canned meat, fruit juices (including in particular apple juice), fish fillets, processed and canned fish and feed for animals (Table 2).

When compared with the 2013, there was a significant increase in the value of cereal products and confectionery (by 41\%), alcoholic and non-alcoholic beverages (by 13\%), milling product (by $1 \%$ ), cocoa products and coffee and tea (by 9\%). On the other hand, there was a decrease in 
the value of export of oil seeds (by 54\%) live animals (by 37\%), fruits (by 29\%) and milk and dairy products. The factors which largely determined the results of the export (especially in the first half of 2016), were the lower harvests of many crops in 2015 and the decrease in the world prices, in particular, the economic slump in the milk market.

Table 2. Product structure of Polish agri-food export

\begin{tabular}{|c|c|c|c|c|c|c|}
\hline \multirow[t]{2}{*}{ HS code } & \multicolumn{3}{|c|}{$\begin{array}{l}\text { Value of export } \\
\text { in mln USD }\end{array}$} & \multicolumn{3}{|c|}{$\begin{array}{c}\text { Share of export } \\
\text { in } \%\end{array}$} \\
\hline & 2010 & 2013 & 2016 & 2010 & 2013 & 2016 \\
\hline 01 & 266 & 239 & 151 & 1,5 & 0,9 & 0,6 \\
\hline 02 & 2761 & 4440 & 4284 & 15,8 & 16,5 & 16,8 \\
\hline 03 & 942 & 1281 & 1347 & 5,4 & 4,8 & 5,3 \\
\hline 04 & 1712 & 2515 & 1886 & 9,8 & 9,4 & 7,4 \\
\hline 05 & 173 & 285 & 260 & 1,0 & 1,1 & 1,0 \\
\hline 06 & 129 & 174 & 135 & 0,7 & 0,6 & 0,5 \\
\hline 07 & 952 & 1215 & 967 & 5,4 & 4,5 & 3,8 \\
\hline 08 & 897 & 1515 & 1075 & 5,1 & 5,6 & 4,2 \\
\hline 09 & 285 & 558 & 606 & 1,6 & 2,1 & 2,4 \\
\hline 10 & 406 & 1114 & 1163 & 2,3 & 4,1 & 4,6 \\
\hline 11 & 148 & 227 & 253 & 0,8 & 0,8 & 1,0 \\
\hline 12 & 261 & 559 & 259 & 1,5 & 2,1 & 1,0 \\
\hline 13 & 7 & 17 & 17 & 0,0 & 0,1 & 0,1 \\
\hline 14 & 4 & 3 & 2 & 0,0 & 0,0 & 0,0 \\
\hline 15 & 425 & 738 & 646 & 2,4 & 2,7 & 2,5 \\
\hline 16 & 872 & 1388 & 1391 & 5,0 & 5,2 & 5,4 \\
\hline 17 & 504 & 774 & 658 & 2,9 & 2,9 & 2,6 \\
\hline 18 & 937 & 1498 & 1634 & 5,4 & 5,6 & 6,4 \\
\hline 19 & 1013 & 1520 & 2137 & 5,8 & 5,7 & 8,4 \\
\hline 20 & 931 & 1461 & 1287 & 5,3 & 5,4 & 5,0 \\
\hline 21 & 1202 & 1705 & 1617 & 6,9 & 6,3 & 6,3 \\
\hline 22 & 578 & 733 & 829 & 3,3 & 2,7 & 3,2 \\
\hline 23 & 520 & 870 & 758 & 3,0 & 3,2 & 3,0 \\
\hline 24 & 1576 & 2041 & 2170 & 9,0 & 7,6 & 8,5 \\
\hline Total & 17499 & 26869 & 25532 & 100,0 & 100,0 & 100,0 \\
\hline
\end{tabular}

For many years, the Polish balance of trade in agri-food products has been positive, and in 2016 it reached a level of USD 7.8 billion. When compared to 2013, it was, however, by 3,7\% lower. Poland records the positive balance of trade with the EU countries (both the old and the new Member States), but its value when compared to 2013 increased by 5,9\% to USD 8,5 billion. On the other hand, there is a constant trade deficit which in 2016 amounted to USD - 0.7 billion.

The highest positive balance was achieved by Poland in trade with Germany (USD 2.0 billion), Britain (USD 1.7 billion), Czech Republic (USD 1.1 billion), France (USD 0.7 billion) and Italy (USD 0.7 billion) i.e. with the countries being the largest importers of Polish agri-food products. On the other hand, the import higher than the export and thus the negative balance occurred in trade with, inter alia, Norway (USD 0.8 billion), Argentina (USD 0.7 billion), Spain (USD 0.3 billion), Denmark (USD 0.3 billion) and Brazil (USD 0.3 billion). When compared to 2013, the 
trade balance improved in case of, inter alia, the United States, Belarus, Saudi Arabia and Hong Kong. The deficit higher than the year before was recorded in trade with, inter alia, Norway, Ukraine, Denmark and Paraguay.

The surplus was generated by Poland mainly in trade in poultry meat, cigarettes, cereal products and confectionery (in total $61 \%$ of the positive balance). The positive balance also existed in trade in chocolate products, beef, smoked fish, wheat, meat products. The highest deficit occurred in trade in fish, animal feed, pork, live pigs, citrus fruit, wine, and palm oil.

\section{Assessment of the diversification level of the Polish agri-food export}

From the analysis of the level of concentration of the Polish agri-food export, measured by the HHI index it results that the export to the EU countries is much more diversified than to the nonEU countries. For the majority of significant importers of agri-food products from Poland among the non-EU countries export is not much diversified and is based on a small product range (e.g. in case of Benin, $94 \%$ of the Polish exports is poultry meat, and in case of Morocco, $74 \%$ is wheat). The situation is slightly different in the non-EU countries being traditionally significant importers markets for Polish food products. This applies to such European countries as Norway or Switzerland, but also Ukraine, Canada, Russia or the United States. The commodity structure of the Polish export to these countries is much more diversified.

As regards the significant non-EU importers of Polish food, the lowest concentration indices HHI are characteristic of the African countries (inter alia, Morocco, Algeria), but also the Asian countries (inter alia, Saudi Arabia, Vietnam). In contrast, the lowest indicators, i.e. the high degree of export diversification occurred in case of the countries bordering on Poland (Lithuania, Germany, Czech Republic or Ukraine). Among other non-EU countries, the low concentration index was characteristic of, inter alia, Norway, Russia, Canada and the United States.

From the analysis of the commodity structure it results that to the countries with the highest concentration index, Poland exported mainly low processed products. These were mainly cereals, dairy products (included powdered milk), cereal products and confectionery (wafers, biscuits) and meat. In turn, the range of products sold in the markets of the countries with the relatively low concentration index was more diversified and included more processed products, including, inter alia, fruit and vegetable products and chocolate products.

The high values of the concentration indices may, on the one hand, evidence the opportunities for the further development of the export of Polish food to the analysed markets, inter alia, through the expansion or better adjustment of the product range to the demand and consumer preferences. On the other hand, it is worth stressing both the climate and cultural differences of the partners as well as the distance between them, as these factors may be a significant barrier to the further development of the agri-food export and limit the possibilities of its diversification.

\section{Conclusion}

The restrictions due to detecting in Poland, at the beginning of 2014, African swine fever (ASF), from suspending the import of pork by the Asian and Customs Union countries and from the embargo imposed by Russia, resulted in the decreased of the agri-food export. In 2016, to compare 2013, the export both to the EU and non-EU countries (especially to Russia) decreased. This means that with the limited opportunities for the growth in the sale of food in the EU, the non-EU outlet markets are and will be increasingly important in managing the production surpluses.

Despite the visible increase in the diversification of the Polish export, the largest importer of Polish food remains Germany, Great Britain, and Czech Republic. It may be expected that the 
EU countries will remain the most important trading partner of Poland, however, the excessive concentration in one outlet market, in case of a collapse in the demand (as shown by Russia), may affect adversely the situation of the entire agri-food sector in Poland.

It seems that the main driving force of the growth may become the future expansion to the nonEU markets, inter alia, in South-East Asia, Africa. These are prospective markets, characterised by a great potential. The Polish export to these countries is still low and includes several basic groups of commodities. The low level of diversification of the Polish export to the analysed countries attests to the still unused sales opportunities. The export of Polish agri-food products to these regions has a chance to grow rapidly in the coming years, due to the good quality of Polish products, competitive prices and European origin. An important obstacle may be cultural barriers, which make adjusting products and marketing strategies to the needs of these markets difficult.

The further development of the Polish export is important for the development of the Polish food industry and, indirectly, also for Polish agriculture, which is a basic source of supply raw materials to the processing industry. In 2016, the export accounted for nearly $40 \%$ of the value of the food industry marketed production. This was twice more than ten years ago. This means that with the relatively constant internal demand, the further development of the food export, through the diversification of outlet markets, determines the development of the entire agri-food sector in Poland.

\section{References}

1. Ambroziak Ł.: The impact of the Russian embargo on Polish agri-food trade." "Food Industry", No 69 (2015) 2-7.

2. Ambroziak, Ł. Bułkowska, M. Role of Poland in foreign trade in agri-food products of the European Union", [in:] Szczepaniak I (ed.), Assessment of competitiveness of Polish food producers in the European Union, Multiannual Programme Series 2011-2014, No 126.1, IAFE-NRI, Warsaw (2014) 28-47,

3. Ambroziak, $Ł$. Szczepaniak, I.: Effects of the Russian embargo on the import of agri-food products. Food Industry, 68 (9), (2014) 2-8.

4. Bułkowska M.: Potential impact of bilateral trade agreements on EU economic growth anticipated effects on the Polish agri-food sector,Prace Naukowe Uniwersytetu Ekonomicznego we Wrocławiu, No 449, (2016) 61-71.

5. Bulkowska M. Opening the Polish agri-food sector to the non-EU countries, „Food Industry", No 5, (2016) 2-6.

6. Hirshman, A.: The paternity of an index. American Economic Review 54 (4-6), (1964) 761-762.

7. . http://wits.worldbank.org.(10.06.2016). 